\title{
THE PROGRESS AND PROSPECTS OF MINING IN
} WESTERN AUSTRALIA. ${ }^{1}$

By A. Montgomery, M.A., F.G.S.

(State Mining Engineer, Western Australia.)

Western Australia is a vast country, justly described as one of "magnificent distances." It comprises 975,920 (or nearly a million) square miles, and extends over twenty-one degrees of latitude, the north part being within the tropics (in $14^{\circ}$ south latitude) and the south approaching the cooler portion of the temperate zone (in $35^{\circ}$ south latitude). The climate, therefore, is very different in different parts of the state. There is a good rainfall along most of the west coast, averaging thirty to forty inches annually, but as we go inland it decreases, and on about 57 per cent. of the area of the state the annual rainfall is under ten inches. Sub-arid conditions therefore prevail in a large portion of the interior, and provision of permanent supplies of fresh water becomes a first necessity of settlement. In the summer months the shade temperature often rises to over $100^{\circ} \mathrm{F}$., and in the tropical parts of the country there is naturally a high average annual temperature, but south of the tropics for the greater part of the year the climate, though warm, is not by any means excessively hot, and in winter it is often quite cold, with occasionally frosts at night. The dryness of the atmosphere enables people to endure a much higher temperature without discomfort than is possible in more humid regions. On the whole, the climate of sub-tropical Western Australia must be regarded as an exceedingly pleasant one, and even within the tropics it has been found that Europeans can live and work with much comfort and excellent health.

There are no high ranges in Western Australia, the altitude of

${ }^{1}$ Abstract of Paper read before the Colonial Section of the Royal Society of Arts, on November 29, I9ro. 
its highest portion being only about 4,000 feet. The greater part of the interior of the country consists of plains I, OOO to I, 50O feet above sea-level, broken by low ridges and island-like low hills. Over the main portion of the central and eastern goldfields there are very few outstanding ranges of hills of any magnitude, but from Peak Hill northwards the country becomes much more hilly, and distinct mountains of some altitude are often visible. In the south of the state also there are some fairly high and steep mountain ridges. There is, however, no great range sufficient to form a source of permanent rivers, and, except in the northwest and southwest regions, where there is a good rainfall, running streams are unknown except during rains. The plains are generally very flat basins dipping towards depressions occupied by salt lakes and saline clay pans. On the edges of these plains there are very often precipitous escarpments ten to fifty or more feet high, known locally as "breakaways," which mark the margins of old lake basins of which the plains were the bottoms. At the top of the escarpments we frequently come on small plateaux, often very level, which are relics of an older marine plain, and on these there are frequently sand dunes, fringing the old lake basins. In the lake-basins the bed-rock is often at a very shallow depth beneath the surface, or even outcropping, but frequently it is covered with detrital material to considerable depths, many wells being sunk seventy to eighty and even over one hundred feet before reaching the bed-rock. It is plain, therefore, that in those old lake basins there has been a great deal of levelling up of old hollows in the bed-rock with detrital materials.

In the districts of the southwest portion of the state, where there is a fairly good rainfall, there are extensive forests of heavy timber, and more inland there are still good timbered belts, which provide excellent firewood and mining timber for the mines. In the Murchison and Mount Margaret districts, however, the heavier eucalyptus timber is replaced by small trees ("mulga"), which supply good firewood and make useful but not first-class mining timber. Still further north the country becomes very open, and is covered with various varieties of grass 
and spinifex, forming good pastoral country. In these parts of the country it is often very difficult and expensive to procure mining timber and firewood, the trees being confined to narrow belts along the main watercourses. The country is, as a rule, remarkably easy to traverse, there being little or no difficulty, other than that of obtaining water, in taking vehicles over it in any direction without having to make roads. The "bush" is very open, and can often be traversed quite readily in a buggy, or even, in a good many places, in a motor-car. This ease of getting about explains at once the extraordinary way in which the goldfields were overrun by prospectors within the first ten years of the gold discoveries. It also explains why it is possible to lay down railways for not much over $\mathfrak{E}_{\mathrm{I}, 500}$ to $\mathfrak{E}_{\mathrm{I}}, 8$ oo per mile.

Gold and other minerals are found more or less all over the explored portions of Western Australia, the principal metallic minerals being gold, tin ores, copper ores, lead ores and iron ores, while coal is the most important non-metallic mineral. The metallic minerals occur in very old igneous and sedimentary rocks, the geological age of which is not yet determined, beyond that it is pretty certain that the most of them are older than the Cambrian period. There is a very complex system of exceedingly ancient metamorphic rocks mingled with igneous intrusives, many of which have become converted into schists, and which may be roughly grouped together as the auriferous greenstones. Breaking through these there are great granitic intrusions, which, in turn, have been pierced by later dykes, both acidic and basic, of different ages. In this great series of old rocks there are doubtless both sedimentary and igneous products of many different ages, the relations of which to one another have not yet been worked out. Lying unconformably on these oldest rocks, we find here and there throughout the country small patches of a younger but still extremely old formation of sedimentary slates and schists (known as the Mosquito Creek series), and apparently of later date than these are the fossiliferous Cambrian beds of the northern part of the state. In the north also 
we have a large development of Devonian rocks, and in the north and west considerable areas of Permo-carboniferous strata. In the most southerly of these last the Collie Collieries have been opened up. The occurrence of patches of cretaceous marine strata and tertiary to recent limestones in widely-separated parts of the state shows that much subsidence and elevation of the country must have gone on since the coal measures were laid down, and numerous physiographical and geological considerations have led me to the conclusion that the country owes the present shape of its surface very greatly to the fact of its having been wholly or in great part submerged beneath the sea within post-Tertiary times.

This very incomplete sketch of the genlogical history of the country may serve to assist in comprehending some of the features met with in mining in it, especially for gold. Except for coal, phosphate rock, gypsum, salt, bauxite and some few other minerals, and when considering the distribution of alluvial gold and tin ore, we may put to one side, from a mining point of view, all the country occupied by the strata of later date than the Devonian period. In the Devonian system we have a very interesting series of auriferous conglomerates (the Nullagine conglomerates), which are in many respects closely analogous to the "bankets" of South Africa, and it is interesting to note that in these beds the gold is pretty certainly of alluvial origin, derived from the erosion of the underlying Mosquito Creek and auriferous greenstone series, both of which teem with auriferous veins. The Devonian and later strata are comparatively little crumpled by orogenic movements, and show little, if any, evidence of ever being penetrated by mineral veins, and it seems very clear that the period of formation of the mineral veins in the older rocks was long anterior to the Devonian, and probably also to the Cambrian period. All the pre-Cambrian strata, whether igneous or sedimentary, are greatly plicated and contorted, the axes of folding running north-northwesterly in the southern part of the state and northeasterly in the northern, conformably with the general direction of the western coast-line. The complex of 
ancient intrusive and metamorphic rocks in which the mineral veins occur, and which we now find at surface, was doubtless once deep in the base of a rising region, probably forming a mountain chain like the Swiss Alps or the Cordilleras of South America. There is much reason to regard it as most probable that the quartz veins carrying the gold and minerals were of very deep-seated origin, most of the vein stuff being really more or less sheared country rock transmuted into quartz by metasomatic change. Most probably they are the result of pneumatolytic processes operating - very likely more or less in connection with volcanic activity-during the period of mountain-forming movement, which was certainly mainly pre-Devonian and probably pre-Cambrian.

The principal gold discoveries may be arranged in belts which correspond very well in direction with that of the general axes of folding of the oldest strata. It is noteworthy that the main granitic areas have so far been found to contain few mineral veins, and that the latter are usually in the greenstone schists and dioritic intrusives not far from the contacts with the granite. When payable mineral veins have been found in the granite they have in almost all cases been quite close to the greenstone contacts. Many of these contacts have probably been lines of very severe faulting movement, the greenstones along the contact being very much sheared and foliated, and the granite being also in some cases converted into schist, which a short distance away soon merges into gneiss and granite. Some of these shear zones along the granite contacts are of great length and persistency, one passing through Southern Cross, for example, being traceable for over sixty miles at least, and they are very notable as containing several important mines, and very numerous smaller auriferous veins.

It has rarely been recognized that it appears to be a very common feature of many West Australian ore bodies that they have been disrupted, by earth movements or faulting, along the planes of the lodes themselves, these movements subsequent to the formation of the ore bodies having re-opened the old line of fracture 
in which the locle was first formed. The good stone is often found suddenly to "cut out"-a term always highly suggestive of some form of faulting-and, as a rule, little search is then made to recover it. Frequently there is a reef of poor or barren quartz present alongside the valuable one, which is of later date of formation than the latter, and which is left standing while the good ore is taken out, but it is uncommon to find any rational deduction being made from the fact that such a condition is prima facie evidence that there was a reopening of the old reef fissure to enable the later poor reef to be formed, and that in the course of the faulting movement which would result, the older reef would almost certainly become much broken and displaced. When it disappears suddenly and the poor reef continues, it is quite usual to assume that the two have joined one another and that the values are simply vanished, instead of search being made for the dislocated continuation of the good ore. It is not contended that this explanation applies to all or even to the most important cases of loss of values in the lodes, but many instances of it have come under my own observation, and there is a good deal of reason to think that many cases of curious separation of lenses of ore containing values may really be explainable by the faulting of an originally continuous body. In dealing with these lodes we are probably handling the case of deposits formed in very early geological times, during a period of much earth movement and plication of the region containing the mines, and therefore particularly liable to show much dislocation of the contained ore veins.

Another characteristic feature of the lodes of Western Australia is the unusual amount of secondary enrichment which appears to have gone on in most of them near the surface, especially in the zone of oxidation above the water level. This has often led to much disappointment when the deeper parts of the lodes have been reached, but it is a feature which is now becoming much better understood than formerly, and for which allowance is to be made. There is, however, much doubt yet as to the depth below surface to which its effects are perceptible. 
In some cases the values disappear so suddenly at the water level that there is a temptation to speculate on the possibility of their having been removed by leaching upwards, there being a certain amount of constant drawing upwards of the groundwater by capillarity to replace the moisture removed by surface vegetation and evaporation. In an arid climate this action may be expected to be more marked than in a humid one. The possibility seems sufficiently feasible to require some sinking to be done in such cases in order to pass through what may be not an enriched but an impoverished zone.

As a matter of fact, good values have been found in Western Australian mines at the greatest depths to which mining has been carried, namely, the 2,650 feet level of the Great Boulder Mine. So far as work has gone at that level, it is true that values have not been so satisfactory as at the 2,500 feet level, and there has been much fear expressed in consequence that this famous mine was at last failing. But some good ore has been obtained, and it must be remembered that at all the levels it has been often easy to miss the best ground until a great deal of exploration has been done. The following of ore in the Western Australian mines is anything but a simple proposition, the ore often being hidden behind what are apparently the well-defined "walls" of the reef, while the lode stuff between these is of little or no value. In almost all the mines of Kalgoorlie it has been found essential to do a great deal of boring across the strike of the reef to locate hidden ore, and the first drive along the lode has often been anything but a true test of its value. This local peculiarity must be recognized and allowed for, and time given to open the ground pretty thoroughly before jumping to conclusions about extinction of values. The whole history of the Boulder Mines from below the oxidized zone has shown a succession of pessimistic forecasts of its early decease, and from time to time the prospects of first one and then another of them have appeared very doubtful. Time and again, however, further exploration has brought about new developments and the position has improved, and there is therefore always much hope that perseverance will be well rewarded. 
All the principal mines show much more variation in their values at different points than is generally understood by the public, and it is owing to this feature of them that it is so difficult-indeed. almost impossible, in many cases-to make really reliable estimates of ore reserves. The only safe course is to keep the mining development a long way ahead of the ore-breaking, to give time for fresh ore bodies to be picked up before the older ones are worked out.

It is undeniable that in Western Australia, as in all other parts of the world, the lower levels of the mines have not been so productive as those nearer the surface, but it does not seem to me that in this respect they have shown any more lack of permanency in depth than those of most other mining fields, nor is there any satisfactory reason yet apparent why values should not be found to persist in them to quite as great depths as in any other mining region say to 4,500 feet as in Bendigo, or even to the immense depth of 6,000 feet at which mining in South Africa has been seriously contemplated. The grounds on which early extinction of values has often been predicted are mainly quite theoretical, and, notwithstanding that great advances have been made towards formulating a science of ore deposits, it cannot be denied that there is still very great conflict of opinion among the best authorities on the subject on the most fundamental propositions as to the mode and conditions of ore formation. For example, not very long ago a discussion was published as to the origin of a certain pyritic ore body, in which one leading authority held the view that it had been formed by magmatic differentiation from an igneous mass, another that it was an ordinary lode of hydrothermal or pneumatolytic origin, and a third that it was a metamorphic sedimentary deposit, all radically different and incompatible conceptions. While one school of opinion regards ore deposits as more or less chemical concentrations from the more superficial rocks of the earth's crust, due to circulation of liquid solutions through them, and another holds equally strongly that they arise mainly from emanations from plutonic sources, there cannot be said to be any accepted theory 
of ore formation on which it is safe to build practical conclusions as to behavior of lodes in depth. The various hypotheses may be useful to guide exploration, but the only practical course is to sink down to see what the ground will show. This has been the mining maxim from its earliest days, and it is still as necessary as ever. No theory is yet so firmly established as to justify deductions being made from it without the check of actual trial.

A great deal of the fear that is expressed as to permanency of ore deposits in depth is often founded on what is really an entirely unproved assumption, though it has a certain amount of prima facie probability, namely, that in a deposit formed by ascending hot waters the metals would be likely to be in solution in the deeper zones while at higher temperature and under high pressure, and would only be deposited as in ascending through the crust of the earth the temperature and pressure are reduced and the solutions come in contact with more superficial waters carrying precipitants. It is somewhat inconsistent that this view should be put forward as a reason for expecting falling off in value in reefs like those of northern New Zealand, which seem plainly to be of hydrothermal origin and outcropping probably at no great depth below the original outlets of the hot springs which formed them, and also for the pneumato-genetic lodes of Kalgoorlie, the portions of which now accessible to us have most probably been formed at great depths under pneumatolytic rather than hydrothermal conditions. And when we come to consider the case of the gold-bearing alaskites, where we seem to be dealing with a transition stage between plutonic dykes and ordinary reefs, it is difficult to understand that either temperature or pressure can necessarily be the determining factors of deposition which they have often been assumed to be.

It seems to me that the mining industry has a right to protest against the very unscientific attitude taken by some persons claiming to be authorities who have allowed themselves to be carried away by deductions from the theories which they adopt with regard to ore deposition, and issued dogmatic statements as to what must happen to ore deposits in depth. In the present state 
of the science any such views can only be tentative, and should be clearly understood to be so. They carry more weight with the investigating public than ought to be allowed to them, views which are the mere speculations of an authority being often taken to represent the demonstrated conclusions of science, and in consequence exploratory work which would be undertaken if these ideas had not been put forward may be restricted or abandoned, to the great detriment of mining. 